\title{
Analisis Film Kartini Dalam Perspektif Kesetaraan Gender
}

\author{
Fansier Hamdja ${ }^{1}$, Fathul Qorib ${ }^{2}$, Sulih Indra Dewi ${ }^{3}$ \\ ${ }^{\text {I} P r o g r a m ~ S t u d i ~ I l m u ~ K o m u n i k a s i, ~ U n i v e r s i t a s ~ T r i b h u w a n a ~ T u n g g a d e w i ~ M a l a n g, ~ J l . ~ T e l a g a ~ W a r n a, ~ M a l a n g, ~} 65144$ \\ E-mail: fansierhamdja@gmail.com \\ ${ }^{2}$ Program Studi Ilmu Komunikasi, Universitas Tribhuwana Tunggadewi Malang, Jl. Telaga Warna, Malang, 65144 \\ E-mail: - \\ ${ }^{3}$ Program Studi Ilmu Komunikasi, Universitas Tribhuwana Tunggadewi Malang, Jl. Telaga Warna, Malang, 65144 \\ E-mail: -
}

\begin{abstract}
The purpose of this study was to determine the efforts of gender equality contained in the Kartini film through the semiotic study of Roland Barthes. Roland Barthes's analysis is used to find out the meaning of denotation, connotation, and myth in an image contained in artistic visualization, act, and dialogue in the film "Kartini". The results of this study that the connotation meaning of the Kartini film in the perspective of gender equality is an effort to fight for gender equality by Kartini as a woman who likes to write and teach literacy to others while denotative meaningthe effort to fight for gender equality in Kartini's film is that Kartini struggles through the path of literacy because literacy is a good way to fight for gender equality, with literacy she breaks Javanese culture which considers women unequal to men andhave abilities below men.Keywords: Semiotics, Kartini, Gender equality.
\end{abstract}

Keywords—: Semiotics; Kartini; Gender Equality.

\section{PENDAhuluan}

Selain membentuk konstruksi masyarakat akan suatu hal, film juga merupakan rekaman realitas yang tumbuh dan berkembang dalam masyarakat dan kemudian memproyeksikannya ke atas layar (Sobur, 2006: 127). Matau dan Ghofur (2019) berpendapat bahwa film, sinetron, dan audio visual mengandung nilai-nilai yang seringkali meresahkan masyarakat. Tetapi di sisi lain, banyak juga film yang mengajarkan norma yang baik bagi masyarakat, salah satunya adalah film komedi Yowis Ben (Wicaksono \& Qorib, 2019). Begitu pula halnya dengan masalah mengenai perempuan di berbagai film selalu menarik dibicarakan. Pandangan masyarakat mengenai perempuan sebagian besar juga terbentuk oleh apa yang selama ini digambarkan oleh media massa, terutama sinema atau film.

Berbagai penelitian banyak mengangkat bahasan seputar persoalan jender dalam film. Misalnya pada penelitian mengenai aspek jender dalam film Indonesia yang dilakukan oleh Abdul Firman Ashaf bekerjasama dengan Dinas Pendidikan menunjukkan bahwa film Indonesia menggambarkan relasi jender yang timpang. Ketimpangan tersebut diidentifikasi melalui tiga hal yaitu: domestifikasi perempuan dan politik relasi jender, segregasi perempuan dalam realitas simbolik film, serta perempuan sebagai objek seks (Wisnubroto, 2010). Penelitian sejenis lainnya juga terdapat pada penelitian berjudul “Representasi Perempuan Jawa dalam Film R.A Kartini” yang ditulis oleh Edwina Ayu Dianingtyas tahun 2010, dari Universitas Diponegoro Semarang.. Film tersebut menunjukan ketidakadilan gender dalam budaya Jawa yang identik dengan ideologi patriarki. Dalam film R.A Kartini ditampilkan diskriminasi dan subordinasi yang dialami oleh perempuan Jawa. Film ini juga menunjukan perjuangan perempuan Jawa untuk melawan ketidakadilan gender yang sangat menindas kaumnya. Pada akhirnya perempuan Jawa dalam film R.A Kartini dapat mendobrak mitos yang selama ini dilabelkan negatif pada diri perempuan Jawa.

Menurut Fakih Mansoer, perempuan itu dianggap irrasional atau emosional sehingga perempuan tidak bisa tampil mempimpin. Anggapan tersebut berakibat munculnya sikap yang menempatkan perempuan pada posisi yang tidak penting (Mansoer. 2008). Anggapan seperti ini menjadikan posisi laki-laki berada di atas perempuan karena dapat bekerja dan memimpin tanpa mendahulukan perasaannya. Sebaliknya perempuan yang dikenal sebagai makhluk yang emosional dianggap tidak cocok untuk menjadi pemimpin.

R.A Kartini adalah putri dari seorang bangsawan yang bernama R.M.A Sosroningrat, Kepala distrik Mayong. Kartini lahir di Desa Mayong, Jepara, Jawa Tengah, pada tanggal 21 april 1879. Kartini menempuh pendidikan di Sekolah Belanda (Europese Lagere School). Setelah lulus sekolah Belanda tersebut, orang tua Kartini melarangnya untuk melanjutkan ke jenjang yang lebih tinggi. Ia di pingit sambil menunggu waktu untuk dinikahi. Pada masa-masa inilah R.A Kartini mengalami dilema yang luar biasa. Untuk menghilangkan perasaan sedihnya dan untuk mengisi waktu luang, Kartini mengumpulkan berbagai macam buku pelajaran dan buku ilmu pengetahuan lainnya untuk dibaca di taman rumahnya.Melalui buku-buku itulah, Kartini tertarik terhadap kemajuan berpikir para perempuan Eropa. Dalam diri Kartini pun muncul pemikiran untuk memajukan perempuan Indonesia. Menurutnya perempuan tidak harus berurusan dengan dapur, tetapi juga harus memiliki ilmu pengetahuan. Dari sinilah kemudian gagasan Kartini mengenai emansipasi wanita muncul. 
Hal menarik yang perlu diteliti dalam film Kartini (2017) adalah perjuangan tokoh R.A Kartini dalam mewujudkan kesetaraan gender antara laki-laki dan perempuan. Perjuangan R.A Kartini yang ingin mendobrak stereotip dimasyarakat mengenai pemikiran bahwa peran mereka seharusnya hanya berada diwilayah domestik. Perempuan diidentikkan dengan pekerjaan rumah tangga dengan segala sifat kefeminimannya, sedangkan laki-laki berperan diluar rumah sebagai sosok maskulin yang memimpin rumah tangga dan bertanggung jawab atas segala hal.

\section{METODE PENELITIAN}

Dalam penelitian ini peneliti menggunakan pendekatan kualitatif dengan mengacu pada teori semiotika Roland Barthes untuk mengetahui makna dari Representasi Film Kartini Dalam Perspektif Kesetaraan Gender. Jenis data yang digunakan berasal dai data primer yakni film Kartini dan data sekunder berasal dari literatur-literatur yang mendukung data. Kemudian pada teknik pengumpulan data terdiri dari dokumentasi studi kepustakaan, kemudian teknik analisa datanya dianalisa dengan mengambil ptongan-potongan scene yang terdapat dalam film Kartini kemudian dianalissi bentuk-bentuk representasi Perspektif Kesetaraan Gendernya.

\section{III.HASIL DAN PEMBAHASAN}

Film kartini merupakan film yang dirilis pada tahun 2017. Film ini bercerita tentang Kartini (yang diperankan oleh Dian Sastrowardoyo) yang tumbuh dengan melihat langsung ibunya yang bernama Ngasirah (yang diperankan oleh Christine Hakim) menjadi orang terbuang di rumahnya sendiri. Hal ini terjadi dikarenakan tidak memiliki darah ningrat dan menjadi seorang pembantu. Sang ayah bernama Raden Sosroningrat (Deddy Sutomo) yang sangat mencintai Kartini tidak berdaya melawan tradisi yang sudah turun temurun. Sepanjang perjalanan hidupnya, Kartini berjuang untuk menyetarakan hak bagi semua orang baik ningrat ataupun bukan. Terutama hak pendidikan untuk perempuan, Bersama kedua saudarinya yang bernama Roekmini (Acha Septriasa) dan Kardinah (Ayushita), Kartini berjuang mendirikan sekolah untuk kaum miskin dan menciptakan lapangan pekerjaan bagi semua masyarakat Jepara.

Film Kartini akan memotret kehidupan sang pejuang wanita ini sejak awal masa hidupnya. Film ini juga berkisah mengenai masa kecil Kartini, juga perjuangannya menuntut kesetaraan hak perempuan dan kaum miskin dalam pendidikan. Film ini dibintangi oleh Dian Sastrowardoyo, Acha Septriasa, dan Ayushita. Selain itu dalam film ini hadir pula Christine Hakim, Deddy Soetomo, Djenar Maesa Ayu, Nova Eliza, Adinia Wirasti, Reza Rahadian, Denny Sumargo, dan lainnya.

Representasi merupakan konsep yang berhubungan dengan pernyataan bagaimana seseorang, kelompok, kegiatan, tindakan. Keadaan sesuatu yang ditampilkan dalam teks (Eriyanto, 2001:289). Sementara itu representasi menurut kamus lengkap bahasa Indonesia, berarti perbuatan mewakili, keadaan diwakili, perwakilan atau gambaran. (Belakangan ini film yang merepresentasikan gerakan feminisme dan kesetaraan gender sudah mulai berkembang luas, baik film produksi Indonesia maupun film-film asing yang direpresentasikan dalam perspektif femnisme. Beragam film direpresentasikan sesuai dengan tujuan sutradara dan produser film mengemas suatu film. Ada yang tujuannya untuk memperbaiki keadaan atau sistem masyarakat yang keliru mengenai pemahaman gender.

Semiotika adalah suatu ilmu atau metode analisis untuk mengkaji tanda. Tanda-tanda adalah perangkat yang kita paka dalam upaya berusaha mencari jalan di dunia ini, di tengah-tengah manusia dan bersama-sama manusia. Semiotika atau dalam istilah Barthes, semiologi, pada dasarnya hendak mempelajari bagaimana kemanusiaan (humanity) memaknai hal-hal (things). Memaknai (to sinity) dalam hal ini tidak dapat dicampuradukan dengan mengkonsumsikan (to communicate). Memaknai bahwa objek-objek tdak hanya membawa informasi, dalam hal mana objek-objek itu berkomunikasi, tetapi mengkonstitusi sistem terstruktur dari tanda (Barthes, 1988:179; Kurniawan, 2001:53, dalam Alex Sobur, 2016;15) Suatu tanda menandakan sesuatu selain dirinya sendiri, dan makna (meaning) ialah hubungan antara suatu objek atau idea dan suatu tanda (Littlejhon, 1996:64). Konsep dasar itu mengikat bersama seperangkat teori yang amat luas berurusan dengan simbol, bahasa, wacana, dan bentukbentuk nonverbal, teori-teori yang menjelaskan bagaimana tanda berhubungan dengan maknanya dan bagaimana tanda disusun. Secara umum studi tentang tanda merujuk pada semiotika.

Teori Barthes hampir secara harfiah diturunkan dari teori bahasa menurut De Saussure. Sebagaimana yang dikatakan Saussure, Barthes juga meyakini bahwa hubungan antara penanda dan petanda tidak berbentuk secara alamiah, melainkan bersifar arbiter. Bila Saussure hanya menekankan penandaan dalam tatanan denotatif, maka Barthes menyempurnakan semiologi Saussure dengan mengembangkan sistem penandaan pada tingkat konotatif. Sebuah tanda adalah gabungan dari satu petanda dan satu penanda. Ranah petanda adalah membahas ranah ekspresi, sedangkan penanda berkaitan dengan ranah isi. Hakikatnya penanda mengisyaratkan catatan yang kurang lebih sama dengan catatan untun petanda, karena penanda merupakan suatu relatum yang definisinya tidak bisa dipisahkan dengan petanda. Penanda dapat dipancarkan dengan materi tertentu yakni kata dan subtansi dari penanda selalu dalam bentuk material yakni bunyi, objek, citra Sedangkan petanda hanya dapat didefinisikan melalui proses penandaan atau dengan cara kausi-tautologis. Petanda adalah sesuatu yang dimaksud oleh orang dengan menggunakan tanda tertentu. Inti dari ranah ekspresi misalnya, subtansi yang mengandung bunyi, diucapkan, nonfungsional sedang subtansi dari isi meliputi misalnya, aspek emosional, ideologis, atau makna positif dari penanda.

Dalam bab ini akan dibahas mengenai tanda tanda yang mewakili atau merepresentasikan upaya dalam menegakkan kesetaraan gender. Dalam upaya kesetaraan gender, film ini menggambarkan tentang upaya yang dilakukan oleh Kartini yang malakukan gerakan di bidang di pendidikan. Di masyarakat Jawa zaman dahulu sendiri, seperti yang tergambar di film kartini 
Website : http://sosial.unmermadiun.ac.id/index.php/sosial

bahwa terdapat beberapa anggapan tentang masyarakat. Salah satu upaya Kartini untuk menegakkan kesetaraan gender awalnya dimulai dari dirinya sendiri dan lalu dia mengajak adik-adiknya untuk ikut serta dalam usahanya. Kartini dan adik-adiknya sangat suka membaca, karena mereka melihat hal itu adalah suatu hal yang penting bagi seorang perempuan karena membaca dapat membuka pikiran dan membuat seseorang mengerti tentang berbagai pelajaran hidup yang penting.

\begin{tabular}{|l|l|l|l|l|}
\hline Visual & Dialog & Audio & Keterangan \\
\hline & $\begin{array}{l}\text { Bacalah, ini buku } \\
\text { bagus }\end{array}$ & $\begin{array}{l}\text { Bacalah,ini buku } \\
\text { bagus. Latar suara } \\
\text { tanpa musik. }\end{array}$ & $\begin{array}{l}\text { Kartini } \\
\text { menyuruh } \\
\text { adiknya } \\
\text { untuk } \\
\text { membaca } \\
\text { buku. }\end{array}$ \\
\hline
\end{tabular}

Scene pada tabel di atas berlatar di dalam kamar Kartini, sebagai tradisi, jika sudah cukup umur maka seorang gadis akan berada di dalam suatu kamar khusus untuk dipingit. Dalam adegan di atas, Kartini berbicara pada adiknya untuk membaca buku.

\begin{tabular}{|l|l|l|l|l|}
\hline \multicolumn{2}{|l|}{ Visual } & Dialog & Audio & Keterangan \\
\hline & & $\begin{array}{l}\text { Kalian sangat } \\
\text { kompak seperti } \\
\text { Het Klaverblad }\end{array}$ & $\begin{array}{l}\text { Kalian benar- } \\
\text { benar membuat } \\
\text { saya kagum. } \\
\text { Kalian sangat } \\
\text { kompak seperti } \\
\text { Het Klaverblad }\end{array}$ & $\begin{array}{l}\text { Kartini bersama } \\
\text { adiknya } \\
\text { membawakan } \\
\text { karya-karya tangan } \\
\text { yang dibuat mereka } \\
\text { untuk diberikan } \\
\text { kepada wanita } \\
\text { belanda. }\end{array}$ \\
\hline
\end{tabular}

Scene di atas bercerita saat Kartini dan adik-adiknya pergi memenuhi sebuah undangan untuk mengunjungi seorang wanita Belanda dengan ditemani oleh ayah mereka. Pada scene tersebut adik-adik Kartini membawa karya terbaik mereka untuk diberikan kepada wanita Belanda tersebut.

\begin{tabular}{|l|l|l|l|l|}
\hline Visual & Dialog & Audio & Keterangan \\
\hline & $\begin{array}{l}\text { Lihat siapa } \\
\text { mereka? }\end{array}$ & $\begin{array}{l}\text { Lihat siapa } \\
\text { mereka? }\end{array}$ & $\begin{array}{l}\text { Sedang } \\
\text { diadakanna } \\
\text { perjemuan } \\
\text { antara bansawan } \\
\text { dan orang } \\
\text { Belanda. }\end{array}$ \\
\hline
\end{tabular}

Scene di atas menceritakan saat Kartini dan adik-adiknya menghadiri acara perjamuan yang dihadiri banyak orang priyayi dan orang-orang Belanda. 
Website : http://sosial.unmermadiun.ac.id/index.php/sosial

\begin{tabular}{|c|c|c|c|}
\hline Visual & Dialog & Audio & Keterangan \\
\hline & $\begin{array}{l}\text { Perintah Kartini } \\
\text { sama dengan } \\
\text { perintahku. }\end{array}$ & $\begin{array}{l}\text { Perintah Kartini } \\
\text { sama dengan } \\
\text { Perintahku, yang } \\
\text { menentang Kartini } \\
\text { sama juga dengan } \\
\text { menentangku }\end{array}$ & $\begin{array}{l}\text { Kartini berusaha } \\
\text { mengumpulkan } \\
\text { masyarakat untuk } \\
\text { membuat suatu } \\
\text { ukiran. }\end{array}$ \\
\hline
\end{tabular}

Scene tersebut menceritakan saat di mana Kartini berusaha bernegosiasi dengan masyarakat desa untuk membuatkannya suatu ukiran.

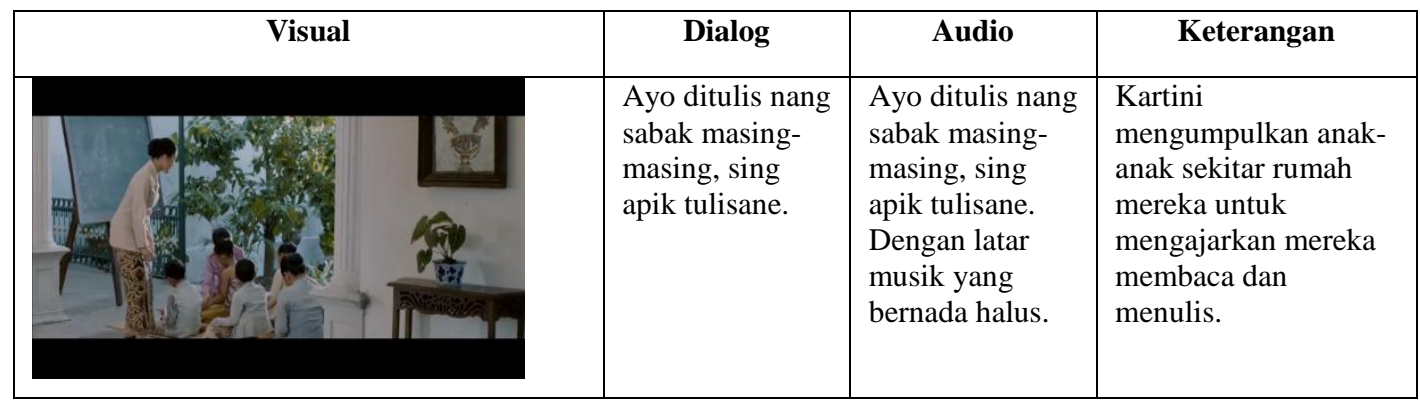

Scene tersebut menceritakan saat Kartini dan adik-adiknya mengumpulkan anak perempuan di sekitar rumahnya dan mengajari mereka baca tulis.

Teori Barthes memfokuskan pada gagasan signifikasi dua tahap, yaitu:

\section{A. Konotasi}

Konotasi adalah makna subjektif atau emosional dalam pengertian bahwa ada pergeseran dari makna umum (denotasi) karena sudah ada penambahan rasa dan nilai tertentu. Kalau makna denotative hampir bisa dimengerti banyak orang, maka makna konotatif ini hanya bisa dicerna oleh mereka yang jumlahnya relative lebih kecil. Berikut ini adalah makna konotasi yang terdapat dalam scene-scened pada film Kartini.

\begin{tabular}{|l|l|l|l|}
\hline Visual & Dialog & Audio & Keterangan \\
\hline Bacalah, ini buku & $\begin{array}{l}\text { Bacalah, ini } \\
\text { buku bagus }\end{array}$ & $\begin{array}{l}\text { Kartini sedang } \\
\text { mengabil } \\
\text { suatu buku } \\
\text { dan hendak } \\
\text { membacanya. }\end{array}$ \\
\hline Konotasi & $\begin{array}{l}\text { Kartini berada di kamar bersama } \\
\text { adiknya dan mengajak adiknya untuk } \\
\text { membaca buku serta bersikap santai } \\
\text { terhadap dirinya. Kartini tidak ingin } \\
\text { mengikuti kultur feodal yang } \\
\text { mengharuskan seorang wanita Jawa } \\
\text { untuk diam dan senantiasa bertutur kata } \\
\text { halus walaupun tidak ada orang. Kartini } \\
\text { mengajari adiknya untuk dapat } \\
\text { mengekspresikan dirinya sendiri dengan } \\
\text { bebas dan menyarankan untuk } \\
\text { membaca buku karena Kartini tahu } \\
\text { membaca adalah cakrawala dunia yang }\end{array}$ & \\
\hline
\end{tabular}


Website : http://sosial.unmermadiun.ac.id/index.php/sosial

\begin{tabular}{|l|l|l|}
\hline & $\begin{array}{l}\text { bisa membebaskan seorang wanita dari } \\
\text { belenggu kehidupan yang tidak tidak } \\
\text { adil gender. }\end{array}$ & \\
\hline
\end{tabular}

Pada scene di atas, Kartini dan adik-adiknya berada dalam satu kamar dan sedang menjalani masa pingitan. Kamar itu bisa menjadi layaknya penjara bagi seorang wanita karena wanita tersebut tidak diperbolehkan untuk berinteraksi dengan dunia luar sampai ada seorang yang melamarnya. Dari hal itu terlihat jelas bahwa Kartini dan adik-adiknya selaku gadis jawa mengalami diskiriminasi gender di mana mereka tidak punya kuasa atas diri mereka sendiri. Seperti yang dikatakan Kartini pada adikadiknya, Kartini memerintahkan adiknya untuk berkata informal dan berlaku santai terhadapnya serta menyuruh adiknya untuk bebas mengekspresikan diri. Hal itu merupakan salah satu upaya Kartini untuk melawan ketidak setaraan gender atas dirinya.

Makna konotasi dari scene di atas adalah bahwa salah satu upaya memperoleh kesetaraan gender adalah dengan membebaskan diri dari belenggu lewat ilmu yang didapat dari membaca buku. Karena tidak peduli di mana pun raga berada, pikiran seseorang akan terus bebas karena buku akan membawanya berkelana ke cakrawala tanpa batas. Karena buku adalah jendela dunia sedangkan wanita pada zaman itu tidak diperbolehkan untuk keluar rumah, sehingga upaya yang dilakukan Kartini adalah terus mengasah pikirannya dengan menambah wawasan melalui buku bacaan dan dia memerintahkan adikadiknya untuk membaca juga, karena sebagai sesama perempuan jawa, mereka mengalami bentuk penindasan yang sama.

\begin{tabular}{|c|c|c|c|}
\hline Visual & Dialog & Audio & Keterangan \\
\hline . & $\begin{array}{l}\text { Kalian } \\
\text { sangat } \\
\text { kompak } \\
\text { seperti } \\
\text { Het } \\
\text { Klaverbla } \\
\text { d }\end{array}$ & $\begin{array}{l}\text { Kalian benar-benar membuat } \\
\text { saya kagum. Kalian sangat } \\
\text { kompak seperti Het } \\
\text { Klaverblad }\end{array}$ & $\begin{array}{l}\text { Kartini bersama } \\
\text { adiknya membawakan } \\
\text { karya ukiran mereka } \\
\text { untuk diperlihatkan } \\
\text { kepada seorang wanita } \\
\text { Belanda, dan wanita } \\
\text { tersebut terkagum- } \\
\text { kagum dengan karya } \\
\text { mereka. }\end{array}$ \\
\hline Konotasi & \multicolumn{2}{|c|}{$\begin{array}{l}\text { Kartini dan adik-adiknya yang sedang } \\
\text { dipingit, keluar rumah untuk menemui } \\
\text { seorang wanita Belanda. Wanita tersebut } \\
\text { sangat ramah terhadap mereka, adik-adik } \\
\text { Kartini membawa karya terbaik mereka } \\
\text { untuk diberikan kepada wanita Belanda } \\
\text { tersebut. Saat ketika seorang gadis jawa } \\
\text { dipingit merupakan saat di mana seorang } \\
\text { gadis dilarang keluar dari rumahnya, } \\
\text { tindakan Kartini dan adik-adiknya yang } \\
\text { keluar rumah pada masa pingitan } \\
\text { mengindikasikan mereka berusaha } \\
\text { melakukan suatu upaya kesetaraan gender } \\
\text { bahwa seorang wanita tidak seharusnya } \\
\text { dikurung dan seorang wanita juga bisa } \\
\text { berkarya. }\end{array}$} & \\
\hline
\end{tabular}

Scene di atas bercerita saat Kartini dan adik-adiknya pergi memenuhi sebuah undangan untuk mengunjungi seorang wanita Belanda dengan ditemani oleh ayah mereka. Pada scene tersebut adik-adik Kartini membawa karya terbaik mereka untuk diberikan kepada wanita Belanda tersebut. Wanita Belanda tersebut terkagung-kagum oleh karya yang diciptakan adik-adik Kartini. Secara tidak langsung, hal itu merupakan suatu upaya untuk menunjukkan bahwa seorang wanita juga bisa membuat suatu karya yang bisa dihargai dan dinikmati oleh orang lain. Di sini lain, pada scene tersebut, mereka juga menentang tradisi pingitan yang dilakukan oleh masyarakat Jawa. Dalam budaya Jawa, seorang wanita sangat diatur tindak tanduknya. Salah satu tradisi yang mengatur kehidupan seorang wanita adalah tradisi pingitan. Tradisi pingitan adalah tadisi yang melarang seorang gadis untuk keluar rumah, awal waktu terjadinya pingitan sangat beragam, ada daerah yang memberlakukan pingitan pada gadis mulai dari 10 atau 12 tahun. Ketika menjalani proses pingitan, seorang gadis dilarang keluar rumah dan harus melakukan pekerjaan domestik, hal itu dimaksudkan untuk mempersiapkan seorang gadis sebelum menikah, agar kelak bisa menjadi seorang wanita yang baik dengan segala ketrampilan mengurus rumah.

Kartini dan adik-adiknya pada scene tersebut sedang dalam masa pingitan, tetapi sang ayah mengizinkan anak-anaknya keluar rumah dengan dipendampingannya. Dengan tindakan Kartini yang keluar rumah saat masa pingitan dan adik-adiknya yang membawa sebuah karya untuk diberikan kepada wanita Belanda, hal itu menunjukkan bahwa Kartini dan adik-adiknya berusaha menunjukkan bahwa seorang wanita tidak hanya mampu di sektor domestik saja tetapi ketrampilan domestik yang dimiliki wanita adalah suatu hal yang luar biasa yang menghasilkan suatu karya yang bisa diapresiasi. 
Website : http://sosial.unmermadiun.ac.id/index.php/sosial

\begin{tabular}{|c|c|c|c|}
\hline Visual & Dialog & Audio & Keterangan \\
\hline & $\begin{array}{l}\text { Lihat siapa } \\
\text { mereka? }\end{array}$ & Lihat siapa mereka? & $\begin{array}{l}\text { Kartini menghadiri } \\
\text { acara perjamuan } \\
\text { yang dihadiri oleh } \\
\text { para bangsawan dan } \\
\text { tamu-tamu Belanda. }\end{array}$ \\
\hline Konotasi & \multicolumn{2}{|c|}{$\begin{array}{l}\text { Kartini dan adiknya berada di suatu } \\
\text { perjamuan menemui Tuan Residen, } \\
\text { seorang pria Belanda yang memiliki } \\
\text { jabatan tinggi dan dihormati banyak } \\
\text { orang. Dalam perjamuan itu, tuan } \\
\text { Belanda tersebut sangat menghormati } \\
\text { dan menghargai Kartini dan menyebut } \\
\text { Kartini sebagai Mutiara Jawa. Tuan } \\
\text { Residen telah membaca tulisan-tulisan } \\
\text { Kartini dan sangat mengapresiasinya. Hal } \\
\text { itu bermakna bahwa Kartini melakukan } \\
\text { suatu upaya kesetaraan gender yang } \\
\text { membuktikan bahwa seorang wanita juga } \\
\text { bagus di sektor luar dan pantas mendapat } \\
\text { pengakuan atas karya mereka. }\end{array}$} & \\
\hline
\end{tabular}

Scene di atas menceritakan saat Kartini dan adik-adiknya menghadiri acara perjamuan yang dihadiri banyak orang priyayi dan orang-orang Belanda. Dalam acara tersebut, Kartini dan adik-adiknya lah satu-satunya wanita Jawa yang menjadi tamu undangan, selebihnya adalah wanita-wanita Belanda dan banyak dari priyayi yang tentu saja harus seorang laki-laki. Dalam pertemuan seperti itu, tidak dijumpai seorang wanita Jawa karena adat pada saat itu melarang seorang wanita untuk melakukan kegiatan di sektor luar, seorang wanita yang belum menikah harus dipingit dan seorang wanita yang sudah menikah harus diam di rumah mengurusi segala kebutuhan suami dan anak-anaknya serta mengurus keperluan rumah lainnya. Scene tersebut menunjukkan suatu pembuktian tentang kesetaraan gender yang dilakukan oleh Kartini bahwa seorang wanita juga bisa mendapat pengakuan dari luar atas kemampuan yang dimiliki.

\begin{tabular}{|c|c|c|c|}
\hline Visual & Dialog & Audio & Keterangan \\
\hline & $\begin{array}{l}\text { Perintah Kartini } \\
\text { sama dengan } \\
\text { perintahku. }\end{array}$ & $\begin{array}{l}\text { Perintah Kartini } \\
\text { sama dengan } \\
\text { Perintahku, yang } \\
\text { menentang Kartini } \\
\text { sama juga dengan } \\
\text { menentangku }\end{array}$ & $\begin{array}{l}\text { Kartini bersama } \\
\text { warga sekitar } \\
\text { sedang } \\
\text { membicarakan } \\
\text { tentang ukiran } \\
\text { yang akan } \\
\text { dibuatnya. }\end{array}$ \\
\hline Konotasi & \multicolumn{2}{|c|}{$\begin{array}{l}\text { Kartini dan ayahnya menemui pengukir } \\
\text { di desa untuk memesan beberapa ukiran } \\
\text { yang akan dikirim ke Belada. Kartini } \\
\text { menemui para pengukir di desa dan } \\
\text { memberdayakan mereka untuk } \\
\text { membuat suatu karya lagi. Dalamm hal } \\
\text { itu Kartini tidak hanya melakukan suatu } \\
\text { upaya untuk mengentaskan }\end{array}$} & \\
\hline
\end{tabular}


Website : http://sosial.unmermadiun.ac.id/index.php/sosial

\begin{tabular}{|l|l|}
\hline & $\begin{array}{l}\text { permasalahan masyarakat desa yang } \\
\text { sepi pesanan ukiran, tetapi juga } \\
\text { melaukukan upaya kesetaraan gender, } \\
\text { dia membuktikan bahwa wanita bisa } \\
\text { bermanfaat di sektor luar. }\end{array}$ \\
\hline
\end{tabular}

Scene tersebut menceritakan saat di mana Kartini berusaha bernegosiasi dengan masyarakat desa untuk membuatkannya suatu ukiran. Pada mulanya pengukir di desa tersebut tidak setuju karena Kartini memesan dengan membawa desain tersendiri dan desain tersebut dinilai mengandung suatu hal negatif sehingga pengukir tersebut menolak. Namun, dengan kemampuan negosiasinya dan dengan bantuan sang ayah, akhirnya pengukir desa mau membuat pesanan Kartini. Kartini memesan beberapa ukiran dan mengirim ukiran tersebut ke Belanda dan Kartini juga mengajak seorang wanita Belanda dari sebuah pameran karya seni untuk berkunjung melihat produksi ukiran Jepara.

Hal itu menunjukkan betapa baik kemampuan Kartini dalam bernegosiasi dan menjalin relasi dengan pihak luar. Hal itu merupakan suatu representasi film ini untuk menunjukkan upaya kesetaraan gender yang membuktikan bahwa wanita juga pintar menjalin relasi dengan luar. Di tambah lagi, setelah menerima pesanan dari Kartini, pesanan untuk ukiran di desa tersebut semakin meningkat, hal itu ditandai dengan di akhir scene itu, ada seorang anak yang menghampiri Kartini dengan membawa ubi-ubian sebagai bentuk terima kasih dan anak tersebut menuturkan bahwa kini dia sekeluarga bisa makan setiap hari karena pesanan ukiran terus berdatangan.

\begin{tabular}{|c|c|c|c|}
\hline Visual & Dialog & Audio & Keterangan \\
\hline 4 & $\begin{array}{l}\text { Ayo ditulis } \\
\text { nang sabak } \\
\text { masing- } \\
\text { masing, sing } \\
\text { apik tulisane. }\end{array}$ & $\begin{array}{l}\text { Ayo ditulis nang sabak } \\
\text { masing-masing, sing } \\
\text { apik tulisane. Dengan } \\
\text { latar musik yang } \\
\text { bernada halus. }\end{array}$ & $\begin{array}{l}\text { Kartini } \\
\text { mengumpulkan } \\
\text { anak-anak } \\
\text { dirumahnya } \\
\text { untuk belajar } \\
\text { membaca, dan } \\
\text { menulis. }\end{array}$ \\
\hline Konotasi & \multicolumn{2}{|c|}{$\begin{array}{l}\text { Kartini dan adik-adiknya } \\
\text { mengumpulkan anak-anak gadis di sekitar } \\
\text { rumahnya dan mengajari mereka baca } \\
\text { tulis. Hal inimerupakan upaya Kartini } \\
\text { untuk menegakkan kesetaraan gender. } \\
\text { Karena banyak anak-anak perempuan } \\
\text { yang tidak bisa mengenyam pendidikan } \\
\text { sama sekali, baik karena alasan orang tua } \\
\text { yang tidak mempunyai biaya atau pun } \\
\text { karena dirasa seorang perempuan tidak } \\
\text { perlu mengenyam pendidikan. }\end{array}$} & \\
\hline
\end{tabular}

Scene di atas menampilkan adegan ketika Kartini mengumpulkan anak-anak perempuan dan wanita di sekitar rumahnya untuk diajari baca tulis. Hal itu merupakan upaya Kartini untuk memperjuangkan kesetaraan gender di daerahnya karena pada saat itu banyak anak perempuan yang tidak bisa merasakan bangku pendidikan sama sekali karena banyak orang tua yang beranggapan bahwa seorang wanita tidak perlu memperoleh pendidikan karena mereka akan bekerja di dalam rumah saja mengurus keperluan rumah sehingga tidak diperlukan sekolah. Kartini mencoba memberikan pedidikan kepada anak-anak yang tidak disekolahkan tersebut karena Kartini meyakini bahwa setiap orang memilik hak yang sama atas pendidikan. Tidak peduli pada akhirnya nanti seorang wanita akan bekerja pada sektor domestik di dalam rumah saja, bagi Kartini kemampuan membaca, menulis dan pengetahuan merupakan hak yang harus diterima oleh semua orang. Kartini menyadari bahwa mengubah nasib wanita Jawa bukanlah hal yang mudah, wanita Jawa sudah terbiasa di madu dan Kartini merasa itu tidak adil sehingga Kartini berkeyakinan bahwa pendidikanlah satu-satunya jalan yang dapat ia tempuh untuk dapat memperjuangkan nasib kaumnya. Tidak hanya anak-anak saja yang diajari baca tulis oleh Kartini, tetapi juga wanita-wanita yang sudah menjadi istri dan memiliki anak. Hal itu dikarenakan Kartini yakin bahwa upaya memperjuangkan kesetaraan yang terbaik adalah lewat jalan pendidikan. 
Website : http://sosial.unmermadiun.ac.id/index.php/sosial

\section{B. Denotasi}

Denotasi adalah hubungan yang digunakan pada tingkat pertama pada sebuah kata yang secara bebas memegang peranan penting di dalam ujaran. Makna deonotasi bersifat subjektif dan langsung, yaitu makna khusus yang terdapat dalam sebuah tanda, dan pada intinya dapat disebut sebagai gambaran sebuah petanda.

\begin{tabular}{|c|c|c|c|}
\hline Visual & Dialog & Audio & Keterangan \\
\hline 8 & $\begin{array}{l}\text { Bacalah, ini } \\
\text { buku bagus }\end{array}$ & $\begin{array}{l}\text { Bacalah, ini } \\
\text { buku bagus }\end{array}$ & $\begin{array}{l}\text { Kartini } \\
\text { mengambil buku } \\
\text { dan menyuruh } \\
\text { saudarinya untuk } \\
\text { membaca buku } \\
\text { tersebut. }\end{array}$ \\
\hline Denotasi & $\begin{array}{r}\text { Kartini d } \\
\text { kamar dan } m \\
\text { Kartini meny } \\
\text { di kamar me }\end{array}$ & $\begin{array}{l}\text { liknya berada di } \\
\text { gang buku. } \\
\text { untuk adiknya } \\
\text { a buku. }\end{array}$ & \\
\hline
\end{tabular}

Pada scene di atas, menceritakan ketika Kartini dan adiknya sedang menjalani masa pingitan. Kartini dan adik-adiknya sedang memegang buku-buku yang tebal. Pada adegan tersebut, Kartini memerintahkan kepada adiknya untuk membaca buku karena buku itu adalah buku bagus. Makna denotasi adalah makna sebenarnya yang umum dan langsung sehingga makna denotasi pada scene di atas adalah Kartini menyarankan adik-adiknya untuk membaca buku.

\begin{tabular}{|l|l|l|l|}
\hline Visual & Dialog & Audio & Keterangan \\
\hline & $\begin{array}{l}\text { Kalian sangat } \\
\text { kompak } \\
\text { seperti Het } \\
\text { Klaverblad }\end{array}$ & $\begin{array}{l}\text { Kalian benar-benar } \\
\text { membuat saya } \\
\text { kagum. Kalian sangat } \\
\text { kompak seperti Het } \\
\text { Klaverblad }\end{array}$ & $\begin{array}{l}\text { Kartini dan adik- } \\
\text { adiknya berkunjung } \\
\text { ke kediaman seorang } \\
\text { Nyonya Belanda. }\end{array}$ \\
\hline
\end{tabular}

Scene di atas menceritakan adegan ketika Kartini dan adik-adiknya berkunjung ke kediaman seorang Nyonya Belanda. Pada gambar tersebut terlihat Kartini dan adik-adiknya sedang berbincang-bincang dengan Nyonya Belanda sedangkan ayah mereka sedang berbicara dengan seorang Tuan Belanda di meja lain di serambi rumah. Pada scene di atas Kartini dan adik-adiknya berbicara dengan Nyonya Belanda, mereka membicarakan banyak hal, nyonya Belanda memuji hadiah pemberian yang diberikan oleh adik-adik Kartini. Makna denotasi adalah makna sebenarnya yang umum dan langsung sehingga makna denotasi pada scene di atas adalah Kartini dan adik-adiknya sedang bercengkrama dengan Nyonya Belanda. 
Website : http://sosial.unmermadiun.ac.id/index.php/sosial

\begin{tabular}{|c|c|c|c|}
\hline Visual & Dialog & Audio & Keterangan \\
\hline & $\begin{array}{l}\text { Lihat siapa } \\
\text { mereka? }\end{array}$ & $\begin{array}{l}\text { Lihat siapa } \\
\text { mereka? (Latar } \\
\text { musik yang } \\
\text { lembut.) }\end{array}$ & $\begin{array}{l}\text { Kartini dan } \\
\text { adik-adiknya } \\
\text { sedang } \\
\text { menghadiri } \\
\text { pesta } \\
\text { perjamuan yang } \\
\text { dihadiri kaum } \\
\text { bangsawan dan } \\
\text { orang-orang } \\
\text { Belanda }\end{array}$ \\
\hline Denotasi & \multicolumn{2}{|c|}{$\begin{array}{l}\text { Kartini dan adiknya berada di } \\
\text { suatu perjamuan menemui seorang } \\
\text { pria Belanda yang memiliki jabatan } \\
\text { tinggi dan dihormati banyak orang. }\end{array}$} & \\
\hline
\end{tabular}

Scene di atas bercerita tentang Kartini dan adik-adiknya yang sedang menghadiri pesta perjamuan yang dihadiri oleh Pribumi dan Belanda. Kartini dan adiknya berada di suatu perjamuan menemui seorang pria Belanda yang memiliki jabatan tinggi dan dihormati banyak orang. Scene di atas berawal ketika Kartini dan adik-adiknya masuk ke ruangan lalu banyak orang yang melihat ke arah mereka, seluruh perhatian tertuju pada Kartini dan adik-adiknya. Lalu seorang Nona Belanda memperkenalkan Kartini dan adik-adiknya kepada seorang Belanda yang memiliki jabatan tinggi. Makna denotasi adalah makna sebenarnya yang umum dan langsung sehingga makna denotasi pada scene di atas adalah Kartini dan adik-adiknya sedang menghadiri pesta perjamuan yang dihardiri oleh priyayi dan pejabat-pejabat Belanda.

\begin{tabular}{|l|l|l|l|}
\hline Visual & Dialog & Audio & Keterangan \\
\hline & $\begin{array}{l}\text { Perintah Kartini } \\
\text { sama dengan } \\
\text { perintahku. }\end{array}$ & $\begin{array}{l}\text { Perintah Kartini } \\
\text { sama dengan } \\
\text { Perintahku, yang } \\
\text { menentang Kartini } \\
\text { sama juga dengan } \\
\text { menentangku }\end{array}$ & $\begin{array}{l}\text { Kartini sedang } \\
\text { bernegosiasi } \\
\text { dengan } \\
\text { masyarakat } \\
\text { sekitar agar } \\
\text { hasil ukirannya } \\
\text { diterima. }\end{array}$ \\
\hline Denotasi & $\begin{array}{l}\text { Kartini dan ayahnya menemui } \\
\text { pengukir di desa untuk memesan beberapa } \\
\text { ukiran yang akan dikirim ke Belada. }\end{array}$ & \\
\hline
\end{tabular}

Scene di atas bercerita tentang Kartini dan Ayahnya yang menemui para pengrajin jepara untuk memesan ukiran. Scene di atas berawal ketika Kartini dan Ayahnya datang menemui para pengrajin jepara. Karena datang rombongan priyayi maka para pengrajin tersebut berkumpul di depan Kartini dan Ayahnya sambil bersimpuh di tanah, tidak berani berdiri karena mereka berkedudukan lebih rendah. Saat itu, Kartini meminta pengrajin itu untuk membuatkan ukiran sesuai dengan gambar rancangan yang telah Kartini bawa akan tetapi pengrajin itu menolak karena dirasa mengukir ukiran tersebut adalah hal yang tabu. Namun ayah Kartini memerintahkan dengan tegas pada para pengrajin untuk memenuhi permintaan Kartini dan mengatakan bahwa perintah Kartini juga merupakan perintahnya. Makna denotasi adalah makna sebenarnya yang umum dan langsung sehingga makna denotasi pada scene di atas adalah Kartini dan Ayahnya beserta rombongan pelayan menemui pengrajin ukiran jepara untuk memesan ukiran. 
Website : http://sosial.unmermadiun.ac.id/index.php/sosial

\begin{tabular}{|l|l|l|l|}
\hline Visual & Dialog & Audio & Keterangan \\
\hline & $\begin{array}{l}\text { Ayo ditulis } \\
\text { nang sabak } \\
\text { masing-masing, } \\
\text { sing apik } \\
\text { tulisane. }\end{array}$ & $\begin{array}{l}\text { Ayo ditulis nang sabak } \\
\text { masing-masing, sing } \\
\text { apik tulisane. Dengan } \\
\text { latar musik yang } \\
\text { bernada halus. }\end{array}$ & $\begin{array}{l}\text { Kartini } \\
\text { mengumpulkan } \\
\text { anak-anak } \\
\text { disekitar } \\
\text { lingkungannya } \\
\text { untuk membaca } \\
\text { dan menulis. }\end{array}$ \\
\hline Denotasi & & & \\
\hline & $\begin{array}{l}\text { Kartini dan adik-adiknya } \\
\text { mengumpulkan anak-anak gadis di sekitar } \\
\text { rumahnya dan mengajari mereka baca } \\
\text { tulis. }\end{array}$ & \\
\hline
\end{tabular}

Scene di atas menceritakan saat Kartini dan adik-adiknya mengumpulkan anak-anak gadis di sekitar rumahnya dan mengajari mereka baca tulis. Kartini mengumpulkan para perempuan di sekitar rumahnya, tidak hanya anak-anak perempuan saja, tetapi ibu-ibu yang sudah memiliki anak juga dikumpulkan untuk diajari membaca dan menulis. Pada scene tersebut Kartini mengajari wanita di daerahnya untuk menghapalkan Alfabet mulai dari A sampai Z dan Kartini menyuruh mereka untuk menulisnya di sabak. Makna denotasi adalah makna sebenarnya yang umum dan langsung sehingga makna denotasi pada scene di atas adalah Kartini dan adik-adiknya mengajari baca tulis pada wanita-wanita di sekitar rumahnya.

\section{IV.KESIMPULAN}

Berdasarkan penelitian yang telah penulis lakukan tentang konsep upaya memperjuangkan kesetaraan gender dalam film Kartini dengan menggunakan analisis semiotika menurut Roland Barthes. Dari penelitian tersebut dapat disimpulkan bahwa dalam film "Kartini" terdapat salah satu scene Kartini berada bersama adiknya di dalam kamar lalu mengajak adiknya unjuk membaca buku. Makna konotasi pada scene ini ialah Kartini tidak ingin mengikuti kultur feodal yang mengharuskan seseorang wanita jawa untuk berdiam diri di rumah. Kartini juga mengajari adiknya untuk dapat mengekspresikan dirinya sendiri dengan bebas dan menyarankan untuk membaca buku karena Kartini tahu, bahwa membaca adalah cakrawala dunia yang bisa membebaskan seorang wanita dari belenggu kehidupan yang tidak adil.

Sedangkan makna denotasi yang dimaksudkan dalam scene ini ialah bahwa dapat dilihat pada scene tersebut bahwa Kartini sedang bersama adiknya pada sebuah kamar dan ia mengambil sebuah buku lalu kemudian diberikan kepada adiknya untuk dibaca, ini menunjukan bahwa Kartini merupakan seorang yang gemar membaca. Dalam salah satu scene juga menjelaskan tentang kemampuan Kartini dalam bernegosiasi kepada pemerintahan belanda untuk bekerja sama dalam suatu pameran karya seni. Pada saat itu Kartini membuat produksi ukiran Jepara. Hal ini menunjukan bahwa perempuan juga pintar dalam hal relasi atau kerja sama, dengan negara lain. Apa yang digambarkan oleh Kartini merupakan representasi dari kesetaraan gender dalam film Kartini itu sendiri.

\section{DAFTAR PUSTAKA}

Antoni. 2005. Kamus Besar Bahasa Indonesia (edisi 3) . Departemen Pendidikan Nasional. Jakarta. Balai Pustaka

Ashcroft, Bill, Garreth Griffith, dan Helen Tiffin. 2002. The Empire Writes Back: Post-Colonial Literatures, Theory \& Practice. London: Routledge

Berger, Arthur Asa 2000. Media Aanalysis Technique. Second edition. Alih Bahasa Setio Budi HH. Yogyakarta: Penerbit Universitas Atma Jay

Bungin, Burhan.2006. Analisis Data Penelitian Kualitatif. Jakarta : Raja Grafindo Persada

Cangara, Hafied. 2005. Pengantar Ilmu Komunikasi. Jakarta: PT Raja Grafindo Persada

Littlejohn, Stephen W. 1996. Theories of Human Communication. Edisi ke-5. Jakarta: Salemba Humanika

Matau, J. B., \& Ghofur, M. A. 2019. Bentuk Kekerasan pada Sinetron Anak Langit. Jurnal Komunikasi Nusantara. Vol 1 No 1, Hal 47-53.

Moeliono, Anton. dkk. 1988. Tata Bahasa Baku Bahasa Indonesia. Jakarta : Balai Pustaka

Nurudin. 2007. Pengantar Komunikasi Massa. Jakarta : PT. Rajagrafindo Persada

Nurudin. 2012. Media Sosial Baru. Yogyakarta: Mata Padi Pressindo

Pena, T. P. 2004. Kamus Besar Bahasa Indonesia. Bandung : Gitamedia Press

Pratista, Himawan. 2008. Memahami Film. Yogyakarta: Homerian Pustaka.

Segers, Rient. T. 2000. Evaluasi Teks Sastra. Terjemahan Suminto A. Sayuti. Yogyakarta: Adicita Karya Nusantara

Sobur, Alex. 2006. Semiotika Komunikasi. Bandung: Remaja Rosdakarya

Sobur, Alex. 2016. Semiotika Komunikasi. Bandung : PT Remaja Rosdakarya

Stokes, Jane. 2007. How To Do Media and Cultural Studies. Yogyakarta : PT. Bentang Pustaka

Wicaksono, Galuh Andi., \& Qorib, Fathul. 2019. Pesan Moral dalam Film Yowis Ben (Analisis Semiotika Charles Sander Pierce). Jurnal Komunikasi Nusantara. Vol 1 No 2, hal 19-25. 